\title{
THE OXYBUTYNIN ABUSE IN ADOLESCENT CASE
}

\author{
Kardas Omer, ${ }^{1}$ Kardas Burcu ${ }^{2}$ \\ ${ }^{1}$ Diyarbakır Selahaddin Eyyubi State Hospital Child and Adolescent Subtance Use Treatment Center, \\ Diyarbakır, Turkey \\ ${ }^{2}$ Diyarbakır Gynechology and Pediatrics Hospital, Diyarbakır, Turkey
}

Primljen/Received 14. 01. 2019. god.

Abstract: Oxybutynin is one of the most commonly prescribed drugs in overactive bladder treatment. Because of its lipophilic structure, it crosses the blood-brain barrier and causes cognitive side effects in the central nervous system. Abuse of the drug is due to its hallucinogenic effect. In terms of substance use disorder, adolescents are one of the groups at risk. In addition to well-known addictive substances, drugs which have sedative, anticholinergic-antimuscarinic, stimulant properties and prescribed for any treatment also can be abused in adolescents with substance abuse. In this article, it is aimed to raise awareness of physicians and health workers about oxybutynin abuse because of the pharmacodynamic characteristics of the drug and its effects on the central nervous system. The health professionals should therefore prescribe this drug with more attention and follow-up those patients.

Key words: oxybutynin, adolescent, addiction, abuse.

\section{INTRODUCTION}

Oxybutynin chloride is one of the most commonly prescribed drugs for the treatment of overactive bladder. It also is indicated in patients with detrusor instability related to neurogenic bladder. It has been studied in and approved for patients over 5 years of age (1). In practice, the minimum therapeutic dose is $5 \mathrm{mg}$ /day and the maximum dose is $20 \mathrm{mg} /$ day. Besides its antimuscarinic effects, oxybutynin has direct anesthetic and smooth muscle relaxant effects (2). Side effects are mainly constipation and dry mouth. There are also side effects in the central nervous system since it is a lipophilic agent so that it can cross the blood-brain barrier. As a result of the studies; concentration problems, decreased alertness and deterioration in decision-making abilities were found in patients with oral oxybutynin use (3). Overdose of the drug may cause anorexia, insomnia, agitation, delusions, hallucinations, confusion,
Prihvaćen/Accepted 01. 03. 2019. god.

and delirium (4). Abuse of the drug is due to its hallucinogenic effect. It causes an increase in neurotransmitters such as dopamine, GABA and serotonin in the synaptic cleft due to anticholinergic effect. This situation leads to aggravationof addiction behavior (5). In terms of substance abuse, adolescents are one of the groups at risk. When the age of onset for substance abuse is evaluated, it is seen that it usually arises in adolescence (6). There are many risk factors that affect substance use in adolescents. The most investigated factors are; age, gender, personality traits, genetic and environmental characteristics. The most prominent one of these factors is to have friends with substance addiction (7). In addition to well-known addictive substances, drugs which have sedative, anticholinergic-antimuscarinic, stimulant properties and prescribed forany treatment also can be abused in adolescents with substance abuse. In this article, we aimed to discuss a case with oxybutynin abuse.

\section{CASE REPORT}

A. A 17year-old male patient who was taking care at the child support institute was brought to our clinic because of substance abuse and excessive irritability. It was learned that his parents had adivorce 6 years ago, the custody was given to the father and he had started living with his father. After the second marriage of his father, he started going away from home, when he had a first encounter with this substance. It was learned that he had robbed for the purpose of accessing the substance and was later handed over to the institution by the police. He told that he started to smoke at the age of 10 . He was smoking 1 pack/day and later he used cannabis and alcohol. He also said that he used alcohol and cannabis 4-5 times a week, and usually was consuming both of them together. On a day when he couldn't find cannabis and alcohol about 6 months ago, he said that 
he was given a pill by his friend and continued using it because he felt good afterwards. We learned that he bought 5 to $10(25-50 \mathrm{mg})$ pills per dayat the pharmacy, and the amount of sleep and appetite decreased when he took them. It was learned that drugs took 5-10 times a day sometimes 2-3 times a day. He also stated increased energy with drugs. The institute officer stated that the pills were brought to the institute by the patient. When he was not able to find any pill, his irritability increased and he forced the staff to prescribe it to him. When he couldn't find any pill he escaped from the institute to apply to the hospital.

As the patient had no family, his developmental history was not taken. Educational history revealed that he completed $5^{\text {th }}$ gradeand gave up school in sixth grade. He told that he learned reading and writing on time but never liked to study, he was generally an unsuccessful student. He said he was bored in class and could not listen to the teacher. He was very active child, he had broken his arm twice and had sustained minor injuries several times.

In the psychiatric evaluation; general appearance was cachectic, consistent with low socioeconomic level, self-care was inadequate. Large and small superficial cuts in the arms which were made for self-destruction were observed. It was learned that the cuts were after substance use. He had a dysphoric mood and his affect was compatible with his mood. Frustration tolerance was low, irritability and anger bursts were observed. It was determined that the rate and the amount of speech were normal.Overthinking about substances, especially oxybutynin was detected in thought content. Concentration problems, hyperactivity and impulsivity were also determined. Visual hallucinations were remarkable only when he took oxybutynin.

DSM-IV-based screening and evaluation scale for attention-deficit and disruptive behavioral disorders filled by the patient was consistent with attention deficit hyperactivity disorder (ADHD) and conduct disorder. BAPI (addiction profile index-adolescent application form) was found to be compatible with substance use disorder and impaired functionality.

As a result of psychiatric evaluation and scales, ADHD,conduct disorder, substance use disorder and oxybutynin abuse were detected in our patient. Since the patient refused to be followed up in the inpatient service and the service was semi-closed, the patient was followed as an outpatient because of the risk of escape. Motivational interview was used. Sertraline (50 $\mathrm{mg}$ /day) and risperidone ( $2 \mathrm{mg}$ /day) were initiated to treat substance use disorder and to reduce craving. Atomoxetine was planned for ADHD. In the evaluation of the patient on the second week after he was discharged from the hospital; it was observed that the irri- tability decreased, he used the medications regularly and no side effects were described. It was learned that the substance and oxybutynin craving were still present but less disturbing. Atomoxetine $25 \mathrm{mg}$ /day was added to the treatment of the patient and then he was called for control.

\section{DISCUSSION AND CONCLUSION}

In adolescence, in addition to the physical changes, there are many psychological changes. Identity acquisition is one of the most important achievements of this period and this situation may turn into anidentity confusion in some individuals. These individuals who are in the process of identity formation are at great risk for substance use. Our patient is at a risky period in terms of substance use. At the same time, the chaotic family structure and divorced parents have made our patient prone to substance use. In many studies, it has been shown that the prevalence of smoking, alcohol and substance use are higher in adolescent individuals with inadequate family functioning and problematic family structure $(6,7)$.

Children and adolescents with ADHD have a higher rate of alcohol, tobacco and illicit substance use than children and adolescents without ADHD (8). In the same study, smoking, cannabis and alcohol use were found 2.5 times higher in ADHD patients. In addition to untreated ADHD, conduct disorder also increases the risk of substance use. The same situation is valid for substance use disorder. The prevalence of ADHD and conduct disorder have been found to be $66 \%$ and $35 \%$, respectively, in a study in which patients with substance use disorder have been evaluated (9). Our patient had previously no proper treatment for his diagnose of ADHD and conduct disorder. Starting to smoke at an early age in our case supports the fact that tobacco is the transition substance. Early smoking increases the risk of substance use for later periods (10). In our case, smoking was followed with the use of cannabis and alcohol.

Oxybutynin abuse can be seen in adolescents, although it is not a common condition. In the two case reports about abuse of this drug in adolescence, the drug dose was similar to our case. After drug use, auditory-visual hallucinations and euphoria have been reported. Tremor, increase of anxiety and sweating have been reported as withdrawal symptoms of the drug (11, 12). Other case reports related to drug abuse belong to adult age group. Two cases of alcohol and substance use disorder were found to have an abuse of oxybutynin. The drug dose of one of these cases was 100 tablets $(500 \mathrm{mg})$ and this is the highest dose we encountered in the literature. Depression, irritability, in- 
somnia and sweating have been reported as withdrawal symptoms (13).

In another case report in the literature, it has been reported that the case who had no substance use before had used oxybutynin in military service. Similar to our case, the subject started oxybutynin with peer effect. It has been reported that it started to be re-used due to fatigue, anger, irritability, carelessness, speech difficulties, introversion symptoms after the discontinuation of the drug use and increased the dose (4). In another case report, it was reported that 60-70 tablets (300-350 mg) oxybutynin was used and psychotic findings were observed similar to our case (14). Psychotic symptoms with low doses of 10-15 mg have been reported in two cases without the abuse of oxybutynin. One of these cases was 7 years old and he used it by mistake. The other patient was 21 years old and he was taking medication with the diagnosis of enuresis nocturna (15). On the other hand, psychotic findings have been not found to occur in another two case reports; although one of the patients with oxybutynin abuse at the prison consumed the drug with a dose of $150 \mathrm{mg} /$ day and the other had $400 \mathrm{mg} /$ day(16).

Oxybutynin is a drug which may cause dependence and differs from other psychotropic agents that we encounter in practice with this property. It has been taken by prescription since March 2017 in Turkey. How- ever, it can be easily prescribed. Individuals with substance use disorder can easily become addicted to the drug. Therefore, the use of anticholinergic drugs should be carefully considered in risky groups and should be prescribed with caution. In this case report, it is aimed to report that oxybutynin is a drug that can be abused and adolescents are at high risk for the abuse of this drug.

\section{Abbreviations}

GABA - Gamma-aminobutyric acid

DSM-IV - Diagnostic and Statistical Manual of Mental Disorders 4th. edition

ADHD - Attention-Deficit/Hyperactivity Disorder

BAPI - Addiction profile index-adolescent application form

\section{DECLARATION OF INTEREST}

The authors declare that there are no conflicts of interest.

\section{Licensing}

This work is licensed under a Creative Commons Attribution 4.0 International (CC BY 4.0) License.

\title{
Sažetak
}

\section{ZLOUPOTREBA OKSIBUTINA U SLUČAJU ADOLESCENATA}

\author{
Kardas Omer, ${ }^{1}$ Kardas Burcu ${ }^{2}$ \\ ${ }^{1}$ Diyarbakır Selahaddin Eyyubi State Hospital Child and Adolescent Subtance Use Treatment Center, \\ Diyarbakır, Turkey \\ 2 Diyarbakır Gynechology and Pediatrics Hospital, Diyarbakır, Turkey
}

Oksibutinin je jedan od najčešće propisivanih lekova u lečenju hiperaktivne mokraćne bešike. Zbog svoje lipofilne strukture, lako prolazi kroz krvno-moždanu barijeru i izaziva brojne neželjene efekte u centralnom nervnom sistemu, koji se pre svega odnose na poremećaje kognicije. Zloupotreba ovog leka može dovesti i do halucinogenih efekata. Odnoseći se na zloupotrebu supstance, može se reći da su adolescenti grupa koja je najviše pod rizikom od zloupotrebe ovog leka. Dobro su poznati sastavni delovi ovog leka, koji izazivaju zavisnost, kao i supstance koje imaju sedativno, antiholinergičko-antimuksarinsko dej- stvo, kao i one koje imaju stimulativne karakteristike i koje su propisivane u svrhe lečenja drugih simptoma i bolesti, a koje adolescenti mogu koristiti i zloupoterbljavati. Cilj ove studije bio je da se proširi svest doktorima medicine i zdravstvenim radnicima u vezi sa zloupotrebom oksibutinina, pre svega zbog njegovih farmakodinamskih karakteristika i efekata na centralni nervni sistem. Zdravstveni radnici i profesionalci, $\mathrm{s}$ toga, moraju da propisuju lek pažljivije i da prate ove pacijente.

Ključne reči: oksibutinin, adolescenti, zavisnost, zloupotreba. 


\section{REFERENCES}

1. Dwyer J, La Grange CA. Oxybutynin. In: Stat Pearls [Internet]. Treasure Island (FL): StatPearls Publishing; 2018. Available from: https://www. ncbi. nlm. nih. gov/books/NBK 499985/.

2. Jirschele K, Sand PK. Oxybutynin: past, present, and future. Int Urogynecol J. 2013; 24(4): 595-604.

3 . Herberg K. Safety in everyday situations and street traffic with the use of medication for incontinence. New investigations into the safety and potential of urological anticholinergic drugs. Med Welt. 1999; 50(50): 217-22.

4. Ruxton K, Woodman RJ, Mangoni AA. Drugs with anticholinergic effects and cognitive impairment, falls and all-cause mortality in older adults: A systematic review and meta-analysis. Br J Clin Pharmacol. 2015; 80(2): 209-20.

5. Can SS. Oksibutinin kötüye kullan2m2 llan bir olgu. T. Psikiyatri Dergisi. 2015; 26(2): 147-8.

6. Gurol DT. Madde Bağımlılığı Acısından Riskli Adolesanlar. İ.Ü. Cerrahpaşa Tıp Fakültesi Sürekli Tıp Eğitimi Etkinlikleri. Adolesan Sağl1ğı II. Sempozyum Dizisi. 2008; 63: 65-8.

7. Steınberg L. Ergenlik. Çok F. (Çeviren). Ankara: Iÿmge Kitabevi, 2007.

8. Ögel K, Erol B. Çocuklarda Sigara, Alkol ve Madde Bağımlılığ1 "Çocuğum Madde Bağımlısı Olmasın". 1. Bask1. Ankara: Morpa Kültür Yayınları, 2005.

9. Lee SS, Humphreys KL, Flory K, Liu R, Glass K. Prospective association of childhood attention-deficit/hyperactivity

\section{Correspondence to/Autor za korespondenciju}

Kardas Omer

Diyarbakır Selahhaddin Eyyubi Devlet Hastanesi

email: kardasomer@gmail.com

phone number: +0905068890696 disorder (ADHD) and substance use and abuse/dependence: a meta-analytic review. Clin Psychol Rev. 2011; 31(3): 328-41.

10. Başay Ö, Yüncü Z, Kabukçu Başay B, Öztürk Ö, Aydın C. Alkol-madde kullanım bozuklukları olan ergenlerin kişilik özellikleri. Anadolu Psikiyatri Derg. 2016; 17(2): 127-35.

11. Hayatbakhsh R, Mamun AA, Williams GM, O'Callaghan MJ, Najman JM.. Early childhood predictors of early onset of smoking: a birth prospective study. Addict Behav. 2013; 38(10): 2513-9.

12. Arslan D, Cansiz MA, Tufa, AE, Öztürk Y. Oxybutynin abuse in an adolescent leading to psychotic symptoms. Anatolian Psychiatry J. 2017; 18(3): 301-2.

13. Kınık MF, Dönder F, Duymaz MK, Karakaya, I. Addiction of Oxybutynin: An Adolescent Case Report. J Addict Res The. 2015; 6(228):2.

14. Kumsar Akkiși N, Okay İT, Dilbaz N. Oksibütinin Kötüye Kullanımı ve Bağımlılığı; İki Olgu Sunumu. Klinik Psikofarmakoloji Bulteni. 2009; 19: 123-4.

15. Aydın O, Aydın PU. Oksibutinin kullanımının yol açtı̆̆1 psikotik bozukluk. Anadolu Psikiyatri Derg. 2016; 17(4): 333.

16. Gulsun M, Pinar M, Sabanci U. Psychotic disorder induced by oxybutynin. Clin drug investig. 2006; 26(10): 603-6.

17. Balasar M, Çiçekçi F. Oxybutynin addiction amongst prisoners: two case reports/Mahkumlar arasinda oxibutinin bagimliligi: Iki olgu sunumu. Anadolu Psikiyatri Dergisi, 2016; 17(3): 77-80. 